\title{
Taxonomic survey of the Araceae Juss. in the coastal region of Piauí state, northeast Brazil, including the Rio Parnaíba Delta
}

\author{
Rafaelle Neves Freitas', Maria Francilene Souza Silva², Jousimar Silva Paiva', \\ Simon Joseph Mayo $^{3}$ \& Ivanilza Moreira de Andrade ${ }^{1,4}$
}

\author{
1 Universidade Federal do Piauí, Herbário Delta do Parnaíba Campus Ministro Reis Velloso, \\ Av. São Sebastião, 2819, CEP 64202-020, Parnaíba, Piauí, Brazil. ivanilzaandrade@hotmail.com \\ 2 Universidade Federal do Ceará, Núcleo de Desenvolvimento de Medicamentos, \\ Laboratório de Oncologia Experimental, CEP 60430-275, Fortaleza, Ceará, Brasil \\ ${ }^{3}$ Royal Botanic Gardens, Department of Identification and Naming, Kew, Richmond TW9 3AE, United Kingdom \\ ${ }^{4}$ Campus Universitário Ministro Petrônio Portela, Programa de Pós-graduação em Desenvolvimento e Meio Ambiente, \\ Av. Universitária, 1310, Bairro Ininga, CEP 64049-550, Teresina, Piauí, Brazil
}

Received on 17.X. 2015

Accepted on 28.1X.2017

DOI 10.21826/2446-8231201772304

ABSTRACT - This is the first taxonomic study of the family Araceae in the state of Piauí, Northeast Brazil. The survey was conducted in four coastal municipalities (Ilha Grande, Luiz Correia, Cajueiro da Praia and Parnaíba) of the state. Eight species were recorded in six genera: Lemna aequinoctialis Welw., L. valdiviana Phil., Montrichardia linifera (Arruda) Schott, Pistia stratiotes L., Wolffiella lingulata (Hegelm.) Hegelm., W. oblonga (Phil.) Hegelm., Taccarum ulei Engl. \& K. Krause and Spathicarpa gardneri Schott. Of these, two are geophytes (T. ulei, S. gardneri) and the others are aquatic macrophytes. Descriptions, illustrations, phenology and habitat information are given for each species as well as a key to their identification.

Keywords: aquatic macrophytes, biodiversity, taxonomy

RESUMO - Pesquisa taxonômica de Araceae Juss. da região costeira do estado de Piauí, Nordeste do Brasil, incluindo rio Delta do Parnaíba. Este é o primeiro estudo taxonômico da família Araceae do estado do Piaú, Nordeste do Brasil. A pesquisa foi realizada nos quatro municípios (Illha Grande, Luiz Correia, Cajueiro da Praia e Parnaíba) da costa litorânea do Estado. Foram registradas oito espécies distribuídas em seis gêneros: Lemna aequinoctialis Welw., L. valdiviana Phil., Montrichardia linifera (Arruda) Schott, Pistia stratiotes L., Wolffiella lingulata (Hegelm.) Hegelm., W. oblonga (Phil.) Hegelm., Taccarum ulei Engl. \& K.Krause e Spathicarpa gardneri Schott. Destas espécies, duas são classificadas como geófitas (T. ulei e $S$. gardneri) e as demais como macrófitas aquáticas. São apresentadas ilustrações, chave de identificação, dados fenológicos e informações sobre os ambientes de ocorrência.

Palavras-chave: biodiversidade, macrófitas aquáticas, taxonomia

\section{INTRODUCTION}

The family Araceae comprises about 118 genera (34 endemic to the Americas) and 3,305 species (Boyce \& Croat 2014), with a cosmopolitan distribution but most diverse in the tropics (Mayo et al. 1997). In Brazil, 473 species from 36 genera are recognized, of which 243 species are endemic, and 120 species and 25 genera are reported in the northeastern region of the country (Coelho et al. 2015).

Araceae are diverse in life form and habitat (Croat 1990). Land-dwelling species include free-standing and creeping terrestrials as well as climbers and epiphytes in tropical forests, and range from small individuals to robust arborescent plants (Mayo et al. 1997). The Araceae are among the leading families of epiphytes and are common in Brazil's Atlantic Forest (Campos et al. 2008). The family is also rich in aquatic macrophytes, classified ecologically as helophytes, rheophytes, submerged or floating (Mayo et al. 1997).
Many scholars have been attracted to study the family because of its remarkable diversity in vegetative and reproductive morphology and anatomy and its ancient geological history (Nauheimer et al. 2012). It has also long been recognized as a strongly supported monophyletic group (Mayo et al. 1997, Cusimano et al. 2011). Due to its highly distinct morphology, and frequently the large size and associated difficulty of preparing specimens in the field, the Araceae are usually under-represented in herbaria. Coupled with the morphological variability they often present, the shortage of field observations has contributed to incomplete taxonomic descriptions and mis-identification and the proliferation of names (Temponi 2005).

A number of studies on Araceae have been conducted in northeastern Brazil, many of which have resulted in new records and the discovery or recognition of new taxa, e.g. Braga (1960), Ramalho (1994), Mayo (1978, 1980), Mayo \& Barroso (1979); Bogner (1980), Mayo (1986), Mayo et al. (1995), Mayo et. al. (1998), Bogner 
\& Goncalves (2002), Haigh et al. (2011), Andrade et al. (2013), Mayo \& Andrade (2013) and Pontes et al. (2014). Articles on species biogeography or genetics have been published by Mayo (1984, 1989, 1990), Gonçalves (2000), Andrade et. al. (2007, 2009) and Pontes \& Alves (2011). Many species from northeastern Brazil have been treated taxonomically in more general reviews, e.g. Anthurium: Croat (1991, 1997), Grayum (1996), Sakuragui et al. (2006); Scaphispatha: Gonçalves (2005), Coelho et al. (2009); tribe Spathicarpa: Gonçalves (2002); Spathiphyllum: Bunting (1960); Syngonium: Croat (1981); Monstera: Madison (1977), among others.

Leaf architecture and morphometrics were studied in taxa of Anthurium, Monstera and Philodendron from northeastern Brazil by Andrade \& Mayo (1998, 2000) and Andrade et al. (2008, 2010), with special emphasis on populations from montane rainforests of Ceará. Silva et al. (2012) studied the leaf morphometrics of Montrichardia linifera occurring in the Rio Parnaíba Delta in Piauí and Maranhão.

Considering the need for conservation of the biodiversity of the coastal region of Piauí, which lies within the Rio Parnaíba Delta Environmental Protection Area, and also the fact that there are currently no studies that report on the diversity of Araceae for ecosystems of the northern region of Piauí, nor for other areas of the state, the objective of this study was to provide a survey of the Araceae of the region. The aquatic macrophytes which comprise most of the species have a significant ecological presence, especially within the Delta vegetation. This is the first strictly taxonomic study of the family in any part of the State of Piauí, as well as a contribution to knowledge of the region's flora, which is still poorly documented.

\section{MATERIAL AND METHODS}

Piauí has the shortest coastline among Brazilian states, at $66 \mathrm{~km}$ long. It is composed of four municipalities (Cajueiro da Praia, Ilha Grande do Piauí, Luís Correia and Parnaíba) located in the Rio Parnaíba Delta Environmental Protection Area. This area (APA: Área de Proteção Ambiental) was established under Federal Decree No. 98897 on August 28, 1996 (IBGE, 2010), and consists of a total area of 362,000 sq.km, $70 \%$ of which lies in the state of Maranhão, $20 \%$ within Piauí and about $10 \%$ within the state of Ceará (IBAMA, 1998).

According to the Köppen Climate Classification System, the climate of the region is tropical megathermal with summer rains and an average annual temperature of $27.5^{\circ} \mathrm{C}$. Average rainfall is $1,223 \mathrm{~mm} /$ year, with April being the wettest month (average rainfall $297.3 \mathrm{~mm} / \mathrm{month}$ ) and September the driest (average rainfall $2.8 \mathrm{~mm} / \mathrm{month}$ ) (Peel et al. 2007).

The coastal vegetation of Piauí State consists of three major physiographic units: the Marine Sector does not have a characteristic vegetation but consists of species which are floristic elements of neighboring areas; the Sand
Sector, a region usually known as the coastal strip, and the Mangrove Sector with its own vegetation type, which has few woody species (Fernandes \& Bezerra 1990).

For this study, 20 field expeditions were carried out between August 2011 and November 2014. All collections were made in the State of Piauí within three of the four coastal municipalities (in bold), at twelve localities (coordinates): Ilha Grande: Barro Vermelho (02 $52^{\prime} 63^{\prime} \mathrm{S}$ and $\left.041^{\circ} 48^{\prime} 11.0^{\prime \prime} \mathrm{W}\right),\left(02^{\circ} 52^{\prime} 52.5^{\prime \prime} \mathrm{S}\right.$ and $\left.041^{\circ} 48^{\prime} 05.5^{\prime \prime} \mathrm{W}\right)$ and $\left(02^{\circ} 52^{\prime} 48.1^{\prime \prime} \mathrm{S}\right.$ and $\left.041^{\circ} 48^{\prime} 11.0^{\prime \prime} \mathrm{W}\right)$, Santo Izidorio (02 ${ }^{\circ} 55^{\prime} 39.99^{\prime}$ 'S and 041 $\left.{ }^{\circ} 46^{\prime} 21.72^{\prime \prime} \mathrm{W}\right)$, Canto do Igarapé

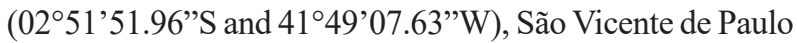
(02 $51^{\prime}$ '9.77'S and 41'48'33.69'W), Cal (02 50'5.8'S and $\left.041^{\circ} 49^{\prime} 12.9^{\prime \prime} \mathrm{W}\right)$, Tatus $\left(02^{\circ} 49^{\prime} 49.5 \% \mathrm{~S}\right.$ and 041 499'44.3”W). Parnaíba: Fazendinha (0253'43.4”S and $\left.041^{\circ} 47^{\prime} 16.0^{\prime \prime} \mathrm{W}\right)$, Braço do Rio Igaraçu (0255'39.99”'S and

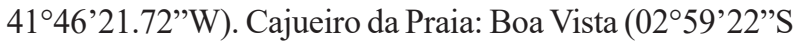
and $\left.041^{\circ} 19^{\prime} 06.9^{\prime \prime} \mathrm{W}\right)$, Canto Grande (02 ${ }^{\circ} 58^{\prime} 56.7^{\prime \prime} \mathrm{S}$ and $\left.041^{\circ} 21^{\prime} 56.3^{\prime \prime} \mathrm{W}\right)$.

Herbarium specimens were prepared from the collected material according to standard procedures (Fidalgo \& Bononi 1989), and identification was carried out using specialized literature (Mayo et al. 1997, Pott \& Cervi 1999, Gonçalves 2002) and with the help of taxonomists specializing in the Araceae. The specimens are deposited in the Delta do Parnaíba Herbarium (HDELTA), at the Federal University of Piauí, Parnaíba campus.

The descriptions and illustrations were prepared from the material collected in the study area. Measures of width/ diameter were obtained from the middle regions of the organs. Data on flowering and ecological observations were obtained during the course of the fieldwork. Data on species distributions were obtained by consulting specialized literature (Coelho et al. 2015).

\section{RESULTS AND DISCUSSION}

Eight species of Araceae in six genera were recorded for the Piauí coast: Lemna aequinoctialis Welw., L. valdiviana Phil., Montrichardia linifera (Arruda) Schott, Pistia stratiotes L., Wolffiella lingulata (Hegelm.) Hegelm., W. oblonga (Phil.) Hegelm., Taccarum ulei Engl. \& K. Krause and Spathicarpa gardneri Schott (Table 1).

Most species were classified as aquatic macrophytes, except for Taccarum ulei and Spathicarpa gardneri, which are geophytes. The macrophyte life forms found were emergent (Montrichardia linifera) and free floating (Lemna aequinoctialis, L. valdiviana, Pistia stratiotes, Wolffiella lingulata and $W$. oblonga).

On the banks of the Igaraçu River, in the municipality of Parnaíba, we observed the occurrence of five species of Araceae sharing the same environment with other macrophyte species such as Eichhornia crassipes (Mart.) Solms, as well as other species that are classified as pollution bioindicators. Montrichardia linifera, Wolffiella oblonga and $W$. lingulata have not been recorded for the state of Piauí prior to this study, according to Coelho et al. (2015). 
Identification key for the species of Araceae from the coastal region of Piauí.

1. Plant a floating aquatic 2

1'.Plant a helophyte (emergent rooted aquatic) or geophyte

2. Plant without roots

2'.Plant with roots ......................................................... 4

3. Frond ovate and curved or slightly falcate, 2-3(-6) fronds united at the vegetative cavity, together forming a colony (rarely united in a star formation) ........ 8. Wolffiella oblonga 3 '. Frond tongue-shaped, 1-2 fronds united (rarely three), the younger arising two thirds from the base of the older one ...... Wolffiella lingulata 4. Fronds (with leaf-like appearance) minute, $1.5-5.0 \mathrm{~mm}$ long, 1-6 per plant 5 4 '. Leaves longer than $2 \mathrm{~cm}$, rosulate, usually more than 6 per plant 4. Pistia stratiotes 5. Two papillae present on upper surface of frond, one at the base and the other near the distal edge of the frond. Frond with three veins, one straight and central and two curved laterals . Lemna aequinoctialis 5' One papilla present on midline of upper surface. Frond with single central vein running from the node almost to the apex 2. Lemna valdiviana 6. Helophyte, $1-6 \mathrm{~m}$ in height, arborescent with a robust elongated stem and leaves concentrated at the apex 3. Montrichardia linifera 6'. Geophyte, less than $1 \mathrm{~m}$ in height, stem subterranean, leaves rosulate or solitary ... 7 7. Leaves 1-4, leaf blade entire with green and silver variegation, spadix completely adnate to the spathe ....... 5. Spathicarpa gardneri 7'. Leaf solitary, leaf blade entire to trilobed during the juvenile phase and bipinnatifid to dracontioid during the adult phase, lacking variegation, spadix free from the spathe 6.Taccarum ulei

1. Lemna aequinoctialis Welw., Apont. 578. 1858 [1859]. (Figs. 1A-C, 2A)

Minute, free-floating aquatic plant. Root one per frond, $0.5-4 \mathrm{~cm}$ long, surrounded at the base by a winged root sheath. Fronds 1-5 $\times 0.5-3 \mathrm{~mm}$, sessile, in groups of 2-3, obovate to lanceolate, chlorophyllous, longer than wide, glabrous, shiny on both sides, apex rounded, base obtuse, margin entire; two papillae present on the upper surface of the frond, one at the base and another near the distal margin of the frond; veins three, one central and two curved laterals. Flower and fruit not observed.

Selected material: Cajueiro da Praia: Boa Vista, 08.XI.2011, Freitas 39, 40 (HDELTA). Ilha Grande: Barro Vermelho, 16.III.2012, Freitas 69 (HDELTA). Parnaíba: Fazendinha, 09.IX.2011, Freitas 31, 33 (HDELTA); Braço do Rio Igaraçu, 30.XI.2011, Freitas, 43, 44, 45, 58, 59, 60 (HDELTA).

Comments: This species, popularly known as "lentilhad'água", is found along the margins of rivers, streams and lakes, sharing the same environment with other aquatic plants such as Wolffiella spp., Pistia stratiotes, Eichhornia crassipes and species from the family Poaceae.

It occurs in tropical and subtropical regions around the world (Landolt 1986, WCSP 2015). In Brazil it occurs in the North (Amazonas), Northeast (Alagoas, Bahia, Ceará, Pernambuco, Piaú, Rio Grande do Norte), Mid-West (Mato Grosso do Sul, Mato Grosso), Southeast (Espírito Santo, Rio de Janeiro), and South (Santa Catarina) (Coelho et al. 2015). A species which has been introduced to many regions, it occurs mainly in shallow lakes, near farms, and other in areas with human influence, where it can cover most of a water body in a short time via vegetative propagation, and can form communities with Wolffiella lingulata and $W$. oblonga.

\section{Lemna valdiviana Phil., Linnaea. 33:239.1864.} (Figs. 1D-G, 2B)

Minute, free-floating aquatic plant. Root one per frond, $0.5-4.3 \mathrm{~cm}$ long, surrounded at the base by a non-winged root sheath. Fronds 1.5-3 × 0.8-2 mm, sessile, in groups of 4-5, oblong-ovate to elongated, floating or slightly submerged below the water surface, shiny medium green on both sides, thin, glabrous, apex rounded, base narrower and asymmetrical, margins entire; one papilla present on the midline of the upper side; veins solitary, central, extending from the node to near

Table 1. Species of Araceae from the coastal region of Piauí State with their occurrence in Brazilian Region and biogeographic and life form classification, based on Pontes \& Alves (2011), Pott \& Cervi (1999) and Coelho et al. (2015).

\begin{tabular}{lccc}
\hline Species & Biogeography & Brazilian Region & Habitat and Life Form \\
\hline Lemna aequinoctialis & Pantropical/subtropical & $\mathrm{N}, \mathrm{NE}, \mathrm{CO}, \mathrm{SE}, \mathrm{S}$ & Lakes and ponds, free floating aquatic \\
Lemna valdiviana & Pantropical/subtropical & $\mathrm{N}, \mathrm{NE}, \mathrm{CO}, \mathrm{SE}, \mathrm{S}$ & Lakes and ponds, free floating aquatic \\
Montrichardia linifera & South America & $\mathrm{N}, \mathrm{NE}, \mathrm{SE}$ & River margins, emergent helophyte \\
Pistia stratiotes & Pantropical & $\mathrm{N}, \mathrm{NE}, \mathrm{CO}, \mathrm{SE}, \mathrm{S}$ & Lakes and ponds, free floating aquatic \\
Spathicarpa gardneri & Brazil & $\mathrm{N}, \mathrm{NE}, \mathrm{CO}, \mathrm{SE}$ & Humid forest, geophyte \\
Taccarum ulei & Brazil & $\mathrm{NE}$ & Caatinga, dry forest, humid forest, geophyte \\
Wolffiella lingulata & Subtropical/tropical & $\mathrm{NE}, \mathrm{CO}$ & Lakes and ponds, floating aquatic \\
Wolffiella oblonga & Subtropical/tropical & $\mathrm{N}, \mathrm{NE}, \mathrm{CO}, \mathrm{S}$ & Lakes and ponds, floating aquatic \\
\hline
\end{tabular}


frond apex. Flowers lateral, ovary ca. $1 \mathrm{~mm}$ long, unilocular, uniovular. Fruit ca. $0.5 \mathrm{~mm}$ long, green, style persistent. Seed ca. $0.3 \mathrm{~mm}$ long, brown with longitudinal ribs.

Phenology: Flowering and fruiting mainly from December to April.

Selected material: Parnaíba: Fazendinha, 09.IX.2011, Freitas 30 (HDELTA).

Comments: Lemna valdiviana was found in an environment in the presence of garbage and animal faeces. The single central vein on the frond differentiates it from $L$. aequinoctialis, which possesses three. The two species can be found in the same place and can easily be confused, but the difference in frond venation, and morphology of the sheath at the root base (winged in L. aequinoctialis and non-winged in L. valdiviana) separates them. L. valdiviana has a high protein content and is considered promising as a food supplement for fish, aside from being able to play the role of phytoremediator, decontaminating or filtering polluted environments (França et al. 2009).

It occurs in the Americas (North, Central and South, WCSP 2015). In Brazil, it occurs in the North (Amazonas), Northeast (Bahia, Paraiba, Pernambuco, Piauí), Midwest (Mato Grosso do Sul, Mato Grosso), Southeast (Rio de Janeiro) and South (Paraná, Rio Grande do Sul, Santa Catarina) (Coelho et al. 2015).

3. Montrichardia linifera (Arruda) Schott, Arac. Betreff. 1: 5.1854 .

(Figs. 1H-N, 2C)

Robust, arborescent helophyte 1-6 m in height; stem dimorphic, the proximal part a horizontal subterranean rhizome that bends upward distally to form the tall aerial stem, which branches at the base to form a new rhizome; aerial stems elongated, erect with grey-green internodes $0.2-26 \times 2-35.9 \mathrm{~cm}$, becoming shorter and greener at stem apex; cataphylls of main stem $2.2-17.3 \mathrm{~cm}$ long. Leaves $3-7$, forming a crown at the stem apex, deciduous below and leaving most of the stem leafless; petiole 14.5-45.9 $\times$ 3-10 cm, green with flat, wide base, curving upwards at the apex to make the leaf blade almost vertical; sheath 8.2-29.5 cm long, more than half the length of the petiole, margin marcescent, apical ligule $0.2-13.9 \mathrm{~cm}$; leaf blade $16.0-56.9 \times 11-45.2 \mathrm{~cm}$, cordate to sagittate, coriaceous, upper surface green, lower surface paler, apex obtuseacuminate, base cordate to sagittate, margin undulate; midrib and primary lateral veins prominent on lower surface and slightly yellowish, primary lateral veins 6-10 pairs. Inflorescences 1-2 per floral sympodium; peduncle 6-11.3 $\mathrm{cm}$ long, cylindrical, dark green. Spathe 10.5-21 × 8-10 cm, erect, slightly constricted, lower third forming closed tube, externally green and internally rose-colored at the base, upper two-thirds forming a spreading blade, boat-shaped, externally green and internally white-cream-colored, entire spathe caducous after flowering. Spadix 8-19 $\times 6-8.2 \mathrm{~cm}$, lower zone female, shorter, yellowish, upper zone male, longer, cream-colored. Flowers unisexual, perigon absent; male flower an androecium of 4-6 free stamens; stamen 4-5 $\times 3-6 \mathrm{~mm}$, truncate at apex, anthers sessile; female flower with prismatic-cylindrical gynoecium 2-3 $\times 1-2$ $\mathrm{mm}$, ovary unilocular, ovules 1-2 per locule. Infructescence olive green, robust, subcylindrical to globose, 6.5-26.5 $\times$ $6.8-30.4 \mathrm{~cm}$. Fruit a berry, 1.9-3.2 $\times 1.8-2.2 \mathrm{~cm}$. Seed $1.5-3 \times 1.5-2 \mathrm{~cm}$, pericarp brown, hard.

Phenology: Flowering and fruiting in every month of the year, but more so in the months of April, July, and from August to December.

Selected material: Ilha Grande: Santo Izidório, 14.V.2011, fl. and fr., Freitas 38 (HDELTA); Canto do Igarapé, 14.IV.2012, fl. e fr., Freitas 70, 71, 72, 73, 74 (HDELTA); Tatus, 08.VII.2012, fl. and fr., Freitas 84, 85, 86, 87 (HDELTA). Parnaíba: Braço do Rio Igaraçu, 24.I.2012, fl. and fr., Freitas 61, 62, 63, 64, 65 (HDELTA).

Comments: Montrichardia linifera forms large and dense populations along the margins of rivers and streams. It is used by the local community for making rafts. The stinging sap from the stem of this species is used to stop bleeding. The mature plant has a dimorphic stem with an underground rhizome, producing erect, aerial branches. It is endemic to South America, occurring from Venezuela in the north to Southeast Brazil (WCSP 2015). Within Brazil it occurs in the North (Amazonas, Amapá, Pará, Roraima), Northeast (Bahia, Ceará, Paraíba, Pernambuco, Piauí, Rio Grande do Norte, Sergipe) and Southeast (Espírito Santo, Rio de Janeiro) (Coelho et al. 2015).

\section{Pistia stratiotes L., Sp. Pl. 2: 963, 1753.}

(Figs. 1O-S, 2D)

Small, free-floating, densely pilose aquatic plant, becoming fixed in shallow water, 7.9-13.5 cm tall, main stem very reduced, producing slender stolons; roots forming a pendent, feathery mass from the plant base with abundant secondary branching, white and brown; stolons 2.6-10.1 cm long, pilose, leafless, light green. Leaves simple, in rosettes, spongy, subsessile; petiole 1-3 cm long, white; leaf blade 2-6 $\times 1.5$ $2.8 \mathrm{~cm}$, obovate-oblong, apex rounded to retuse; primary veins $5-8$, parallel and distinct, prominent on the abaxial surface. Inflorescence solitary in the leaf axil, erect to suberect, very small and much shorter than leaves, 5-7 per plant, 0.9-1.6 $\mathrm{cm}$ long; peduncle 3-6 $\mathrm{mm}$ long. Spathe pubescent on both surfaces, constricted centrally, 6-10.1 × 6-8 mm, basal part adnate to the ovary, then margins free and strongly lobed inwards forming a central open chamber around the stigma and an upper expanded lamina around the male zone, lamina ovate, expanded, whitish-green, white on inner surface, apex acuteacuminate, recurved. Flowers unisexual, perigon absent; upper male spadix zone 2-3 mm long, consisting of a whorl of ca. 5 
male flowers borne on a short white axis, surrounded at the base by a thin, green, lobed, glandular flap, each male flower consisting of a yellow synandrium of 2 connate stamens; lower female zone consisting of a solitary pistil, $5-7 \mathrm{~mm}$ long, with a green glandular flap immediately distal to it, ovary 3-4 × 2-3 $\mathrm{mm}$, ovoid, oblique to the axis of the spathe, unilocular, ovules basal, ca. $1 \mathrm{~mm}$ long, numerous, style distinct, much narrower than ovary, ca. $2 \mathrm{~mm}$ long, curved to become subparallel to spadix axis, stigma subcapitate, slightly broader than style, translucent white. Fruit a thin-walled berry, 5-7 $\times 3-3.1 \mathrm{~cm}$, ellipsoid, green, dehiscence irregular. Seed 1.2-1.5 mm long, 3-9 per fruit, brown, barrel-shaped, surface reticulate-alveolate.

Phenology: Flowers throughout the year.

Selected material: Ilha Grande: Barro Vermelho, 09.IX.2011, Freitas 35 (HDELTA); Barro Vermelho, 18.I.2012, fl. and fr., Freitas 48, 49, 50, 51, 52 (HDELTA); Cal, 13.VI.2012, fl. and fr., Freitas 83 (HDELTA); São
Vicente de Paulo, 18.I.2012, fl. and fr., Freitas 53, 54, 55, 56, 57 (HDELTA). Parnaíba: Braço do Rio Igaraçu, 30.XI.2011, fl. and fr., Freitas 36 (HDELTA).

Comments: This species, commonly known as "alfaced'água", occurs in large populations along the margins of rivers, lakes and ponds, and is usually found together with Lemna species. According to local people, the leaf is used as a tea to relieve menstrual pain. It is also used as an ornamental plant, but can be a harmful weed that covers a great part of the surface of still-water bodies and limits the use of water supplies. P. stratiotes is most abundant in very polluted lakes and streams, harbouring large populations of snails. It is a food source for many animals, such as snails, insects, fish and birds and has a great capacity for sewage bioremediation (Pott et al. 1999).

P. stratiotes occurs throughout the tropics and subtropics (WCSP 2015). In Brazil it occurs in the North (Acre, Amazonas, Amapá, Pará), Northeast (Alagoas, Bahia, Ceará, Pernambuco,

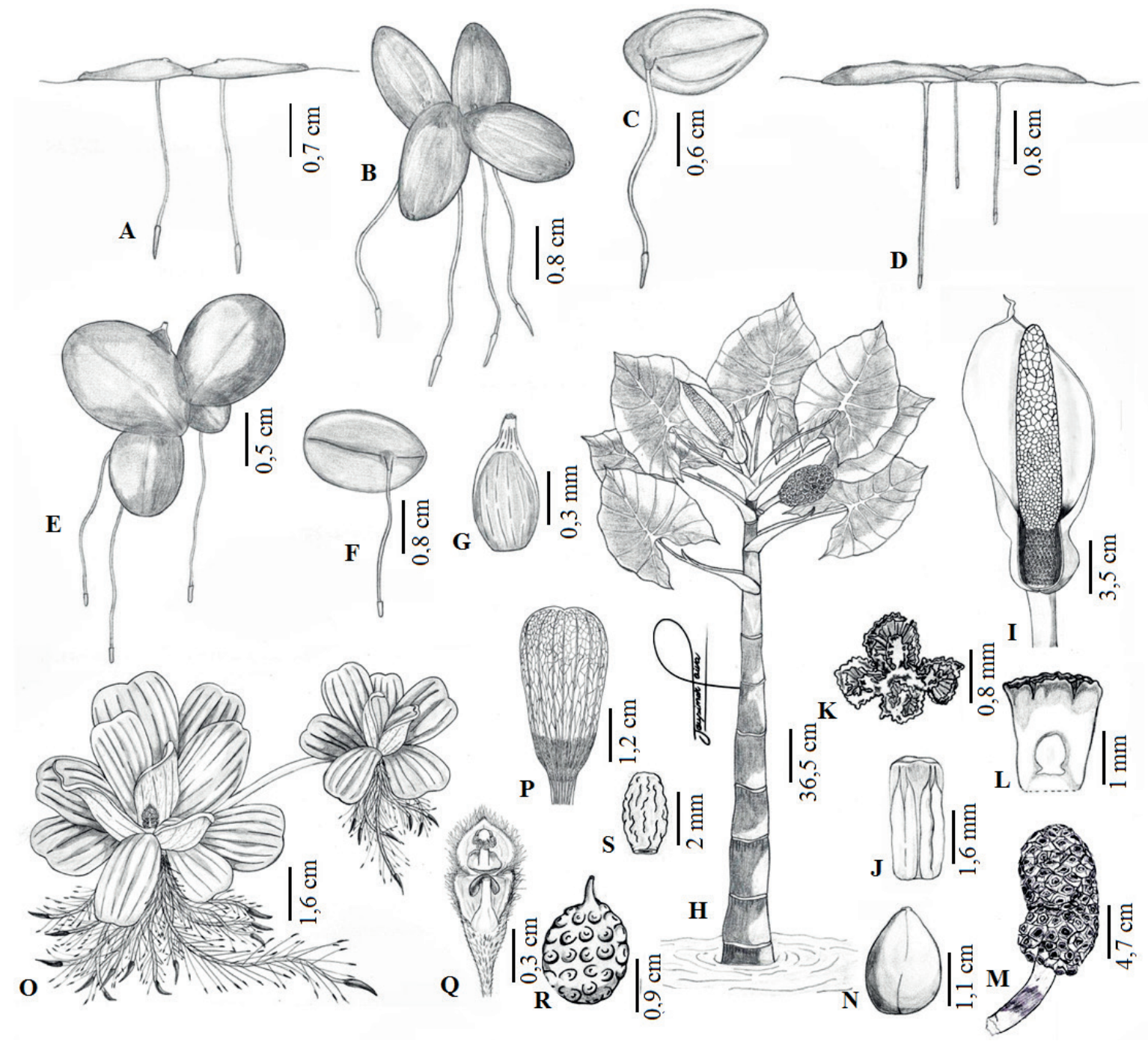

Figs. 1 A-S. Araceae from the coastal region of Piauí. A-C. Lemna aequinoctialis Welw.; A. Habit, side view; B. Habit, seen from above; C. Frond showing three veins; D-G. Lemna valdiviana Phil. D. Habit, side view; E. Habit, seen from above; F. Frond showing single vein; G. Fruit; H-N. Montrichardia linifera (Arruda) Schott. H. Habit; I. Inflorescence; J. Stamen; K. Stigma see from above; L. Female flower in longitudinal section showing ovule; M. Infructescence; N. Seed; O-S. Pistia stratiotes L. O. Habit; P. Leaf blade seen from above showing venation; Q. Inflorescence; R. Fruit; S. Seed. 


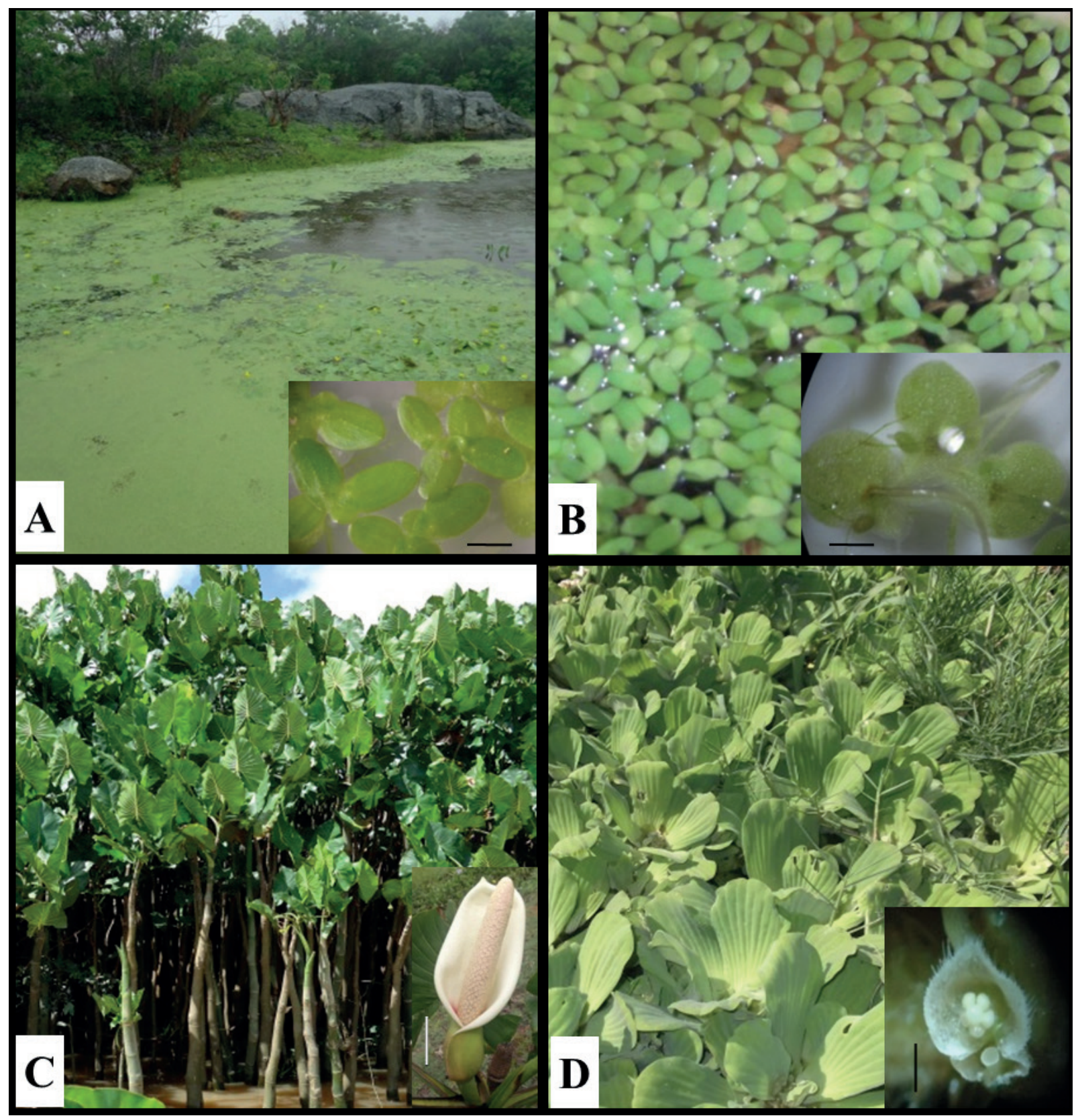

Figs. 2 A-D. Araceae from the coastal region of Piauí. A. Lemna aequinoctialis Welw., population with fronds seen from above (detail); B. Lemna valdiviana Phil., population with fronds seen from below (detail); C. Montrichardia linifera (Arruda) Schott, population with flowering inflorescence (detail); D. Pistia stratiotes L., population with inflorescence in flower, showing spathe surrounding stigma below and whorl of male flowers above (detail). Bars: Fig. $\mathbf{A}=0,5 \mathrm{~mm}$; Fig. $\mathbf{B}=0,15 \mathrm{~mm}$; Fig. $\mathbf{C}=4,75 \mathrm{~cm}$; Fig. $\mathbf{D}=0,5 \mathrm{~mm}$.

Piauí, Rio Grande do Norte, Sergipe), Midwest (Goiás, Mato Grosso do Sul, Mato Grosso), Southeast (Espírito Santo, Minas Gerais, Rio de Janeiro, São Paulo) and South (Paraná, Rio Grande do Sul, Santa Catarina) (Coelho et al. 2015).

5. Spathicarpa gardneri Schott, Bonplandia (Hannover) 6: $124,1858$.

(Figs. 3A-C, 4A)

Small geophyte, $10-23 \mathrm{~cm}$ tall, stem tuberous, globular or elongated, $0.6-1.3 \times 0.5-2.1 \mathrm{~cm}$. Leaves $1-4$, usually erect; petiole 7.2-14 cm long, upper part green, lower part white, canaliculate to cylindrical; sheath winged, $1-2 \mathrm{~cm}$ long; leaf blade 3.3-11 × 2.8-6.3 cm, simple, general outline ovate, elliptic, narrow elliptic, or lanceolate, adaxial surface dark green with silvery green patches, abaxial surface shiny, chartaceous to membranaceous, apex short, acuminate to cuspidate, base truncate, cordate to subcordate or slightly hastate, rarely asymmetric, margin entire, primary lateral veins 3-6 per side, prominent on abaxial surface. Inflorescence solitary, peduncle $15-22 \mathrm{~cm}$ long. Spathe 3.6-5.2 $\times 0.8-1 \mathrm{~cm}$, erect, elliptic to lanceolate, persistent, not constricted, pale green on adaxial surface, darker green on abaxial surface. Spadix 2.2-3.5 cm long, green, entirely adnate to the spathe. 


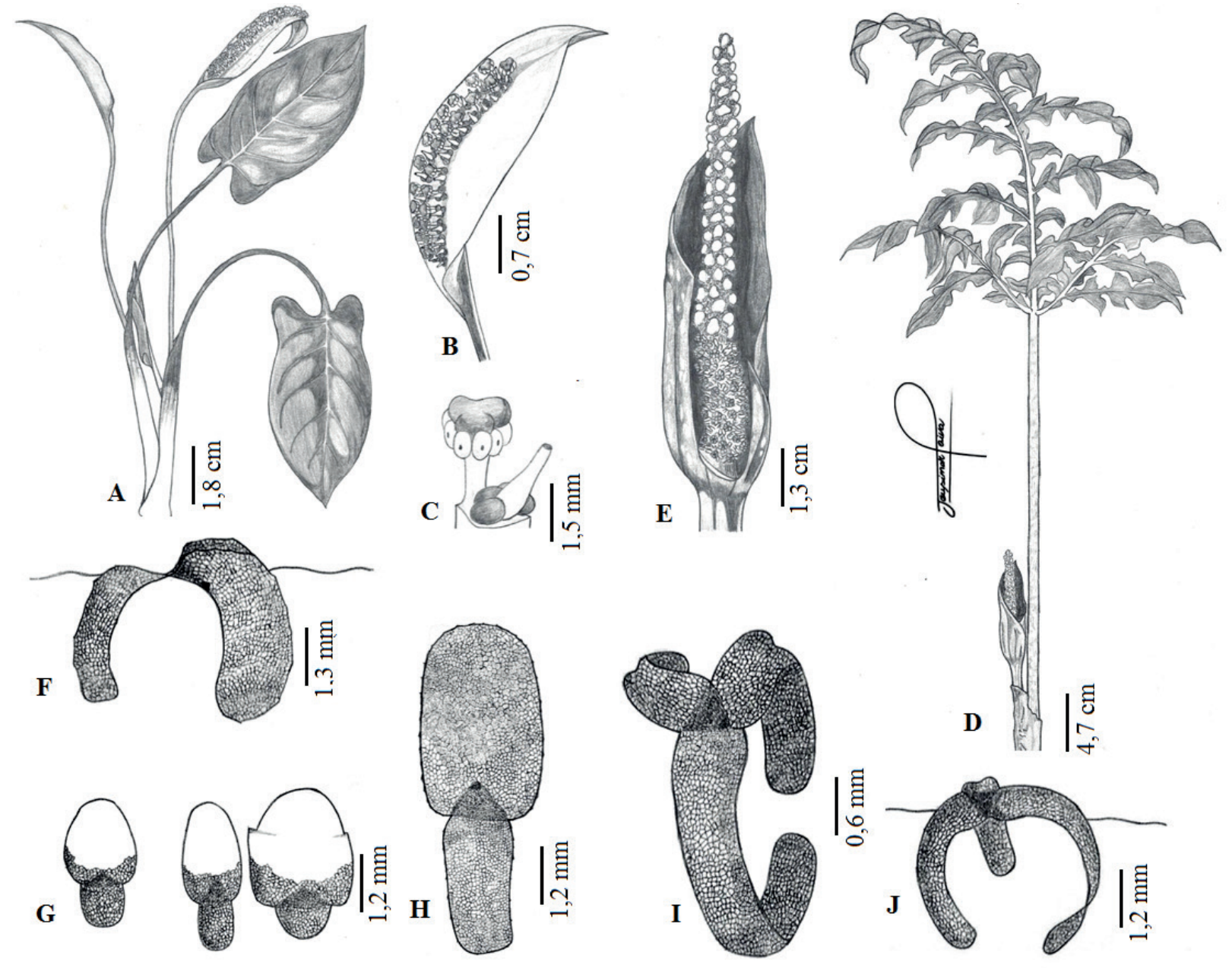

Figs. 3A-J. Araceae from the coastal region of Piauí. A-C. Spathicarpa gardneri Schott. A. Habit; B. Inflorescence; C. Detail of male (left) and female (right) flowers: D, E. Taccarum ulei Engl. \& K. Krause. D. Habit, showing single leaf and inflorescence; E. Inflorescence; F-H. Wolffiella lingulata (Hegelm). Hegelm. F. Habit, side view of plant with two united fronds; G. Morphological variation of two-fronded plants; H. Plant with two fronds, seen from above; I, J. Wolffiella oblonga (Phil.) Hegelm. I. Plant with three united fronds seen from above; J. Habit in relation to the water surface, side view of three-fronded plant.

Flowers unisexual, perigone absent; male flower consisting of a stipitate synandrium, anthers subglobose, pale yellow, in a subapical whorl, apex of synandrium pale green, shallowly lobed; female flower consisting of a single flask-shaped gynoecium surrounded by several fungiform staminodes, ovary unilocular; Fruit a berry, 5-7 × 1-4 mm, dark green, utricle, ovoid. Seed 3-4 mm long, light green when fresh, ovoid with longitudinal ridges.

Phenology: Flowers from June to January.

Selected material: Cajueiro da Praia: Canto Grande, 05.IV.2013, fl. and fr., Freitas 98, 99, 100, 101, 102 (HDELTA).

Comments: Spathicarpa gardneri occurs in areas of caatinga, cerrado, mesophytic forests, on limestone outcrops and in the restinga habitat, together with Taccarum ulei, and the density of individuals can be fairly high. The species has ovoid seeds with conspicuously verrucose testa (Gonçalves 2002).
It is endemic to tropical Brazil, distributed in the North (Tocantins), Northeast (Bahia, Ceará, Maranhão, Piauí, Rio Grande do Norte), Midwest (Distrito Federal, Goiás), and Southeast (Minas Gerais) (Coelho et al. 2015).

6. Taccarum ulei Engl. \& K. Krause, Notizbl. Bot. Gart. Berlin 6: 116. 1914.

(Figs. 3D-E, 4B)

Large geophyte to ca. $60-95 \mathrm{~cm}$ tall, stem an underground tuber, 1-2 $\times 1-3 \mathrm{~cm}$, externally brown and whitish within. Leaf solitary; petiole 40-92 × 1-1.5 $\mathrm{cm}$, cylindrical, at the base colored whitish, green and pink, with or without variegation, and above colored brown and green, variegated with transverse, irregular, oblique patches contrasting white on the upper side and dark green or brownish on the lower side; leaf blade $25-109.5 \times 20-67 \mathrm{~cm}$, entire to trilobed in the juvenile phase and bipinnatifid to dracontioid in the adult phase, membranaceous, ultimate lobes (leaflets) ovate, apex 


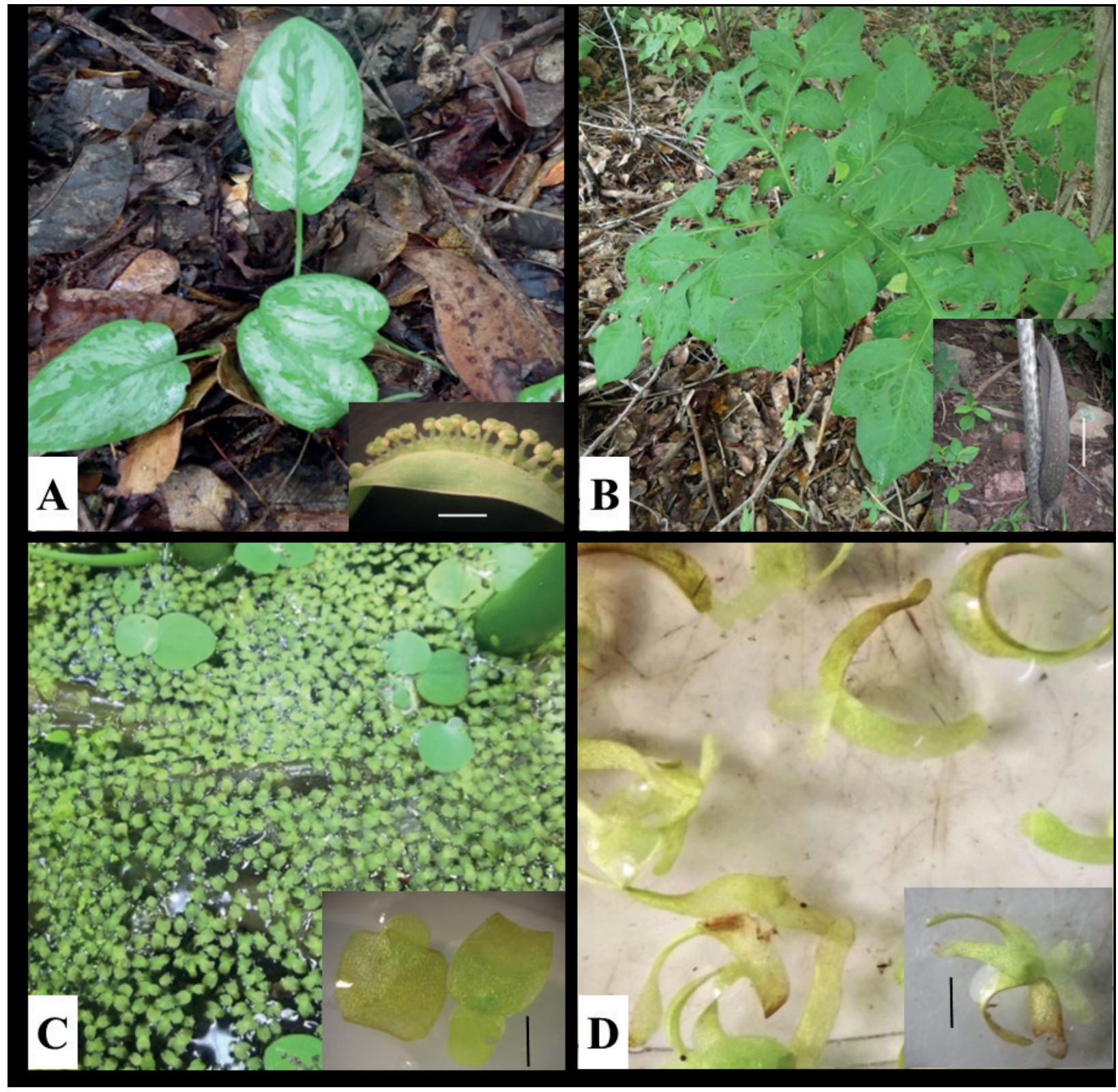

Figs. 4. A-D. Araceae from the coastal region of Piauí. A. Spathicarpa gardneri Schott, plant on ground seen from above, inflorescence in side view (detail); B. Taccarum ulei Engl. \& K. Krause, surface view of single leaf, inflorescence and petiole (detail); C. Wolffiella lingulata (Hegelm). Hegelm., population of numerous plants in habitat, two plants (detail); D. Wolffiella oblonga (Phil.) Hegelm., plants floating in specimen dish. Bars Fig. $\mathbf{A}=0,9 \mathrm{~cm}$; Fig. $\mathbf{B}=5,7 \mathrm{~cm}$; Fig. $\mathbf{C}=0,2 \mathrm{~mm}$; Fig. $\mathbf{D}=0,5 \mathrm{~mm}$.

acute, margin entire, adaxial side dark green, abaxial side concolorous with prominent white or vinaceous veins. Inflorescence solitary; peduncle $19-24 \times 1 \mathrm{~cm}$, canaliculate with a flattened portion. Spathe $12-20 \times$ $0.5-4 \mathrm{~cm}$, ovate-oblong, light green and pink internally towards base, dark green externally, variegated obscurely on both surfaces, apex cuspidate. Spadix projecting beyond spathe, erect, $10-15 \mathrm{~cm}$ long, male zone much longer than female zone, spadix axis purplish between the flowers. Flowers unisexual, perigon absent; male flower consisting of a synandrium of connate stamens with a smooth, hemispherical, cream-white or pink stigmatoid connective protruding well above the light-orange anthers; female flower consists of a single gynoecium surrounded by a whorl of 4-5 \pm clavate staminodes white and ovoid at the apex, pink at the base, ovary purplish-pink, stigma large, slightly \pm 6 -lobed, light yellow, wider than the style. Berry pink-green, with 2-10 loculi, most berries with 6 locules. Seeds 1 per locule, 4-8 mm long, cream-colored with red spots over the entire surface.

Phenology: In full bloom from January to June.

Selected material: Cajueiro da Praia: Canto Grande, 30.IV.2012, fl. and fr., Freitas 75, 76, 77, 78,79, 80, 81 (HDELTA).

Comments: Taccarum ulei can be recognized by its maculate petiole with dark green, longitudinal striae, and 
the solitary dracontioid leaf, with 3 to 5 pairs of deeply pinnatifid lobes. It occurs from the coastal forests of the "tabuleiro" (the low coastal plateau) and restinga to areas of caatinga in the semi-arid region further inland. It grows in temporarily moist soils, occasionally completely exposed to the sun (Gonçalves 2002).

This species is endemic to Northeast Brazil (Gonçalves 2002) and has been recorded in the states of Alagoas, Ceará, Maranhão, Paraíba, Pernambuco, Piauí, Rio Grande do Norte and Sergipe (Coelho et al. 2015).

7. Wolffiella lingulata (Hegelm). Hegelm., Bot. Jahrb. Syst. 21(3): 303-304. 1895.

(Figs. 3F-H, 4C)

Minute, free-floating aquatic plant, 3-5 $\mathrm{mm}$ tall, stemless, roots absent. Fronds free, 2.1-4.0 $\times 1.2-3 \mathrm{~mm}$, solitary or with two fronds joined together (rarely three), longer than wide, tongue-shaped, membranous, delicate, glabrous, shiny medium green on upper and lower sides, concave on upper side with raised lateral margins, entire, with or without stomata, the younger arising two thirds from the base of the older one, air spaces present from the base up to half or two thirds of the frond length, a sequence of elongated cells present between the midline and the edge of the vegetative cavity wall, apex rounded, sometimes narrower than the base, base slightly truncate, epidermis uniseriate with cells containing chloroplasts. Flowers and fruits not seen.

Selected material: Parnaíba: Braço do Rio Igaraçu, 30.XI.2011, Freitas 37 (HDELTA).

Comments: Wolffiella lingulata forms communities with Lemna spp. It is primarily associated with the roots of aquatic macrophytes. This species was found along the banks of a polluted stream near a slaughterhouse, along with Pistia stratiotes and Eichhornia crassipes.

This species occurs in tropical and subtropical America (WCSP 2015). In Brazil, it occurs in the Northeast (Bahia), and Midwest (Mato Grosso do Sul, Mato Grosso) (Coelho et al. 2015).

8. Wolffiella oblonga (Phil.) Hegelm., Bot. Jahrb. Syst. 21(3): 303.1895 .

(Figs. 3I-J, 4D)

Minute free-floating aquatic plant, $0.6-5 \mathrm{~mm}$ in height, stemless, roots absent. Fronds 2-3 (-6), asymmetric, curved or slightly falcate, ovate, submerged in the surface water film, 2-6 united at the vegetative cavity, together forming a colony (rarely united in a star shape), slender, apex rounded, tapered, base emersed, oblique, margin entire. Flowers and fruits not seen.

Selected material: Parnaíba: Braço do Rio Igaraçu, 29.V.2012, Freitas 82 (HDELTA).
Comments: Wolffiella oblonga sometimes forms starshaped colonies. This species was found along the margins of a polluted stream near a slaughterhouse, along with Pistia stratiotes, Eichhornia spp., Lemna spp. and Wolffiella lingulata.

This species occurs in tropical and subtropical America (WCSP 2015). In Brazil, it occurs in the Northeast (Bahia), Midwest (Mato Grosso do Sul, Mato Grosso), and South (Paraná, Santa Catarina) (Coelho et al. 2015).

\section{ACKNOWLEDGMENTS}

We thank CNPq for financial support for the project Biodiversidade de Macrófitas Aquáticas do Delta do Parnaiba (processo no. 503494-2009-7), the project MacDoubles Fernandes do Nascimento de Apoio a Ciência, Tecnologia e Inovação, Prefeitura de Parnaíba, Piauí and the System for Authorization and Information on Biodiversity (ICMBio-SISBIO) and the project team, for their help in the field study.

\section{REFERENCES}

Andrade, I.M. \& Mayo, S.J. 1998. Dynamic shoot morphology in Monstera adansonii Schott var. klotzschiana (Schott) Madison (Araceae). Kew Bulletin 53: 399-417.

2000. Dynamic shoot morphology in root-climbing Araceae: Philodendron rudgeanum Schott and P. fragrantissimum (Hook.) G. Don. Feddes Repertorium 111(5-6): 295-314.

Andrade, I.M., Mayo, S.J., Kirkup, D. \& Van den Berg, C. 2008. Comparative morphology of populations of Monstera Adans. (Araceae) from natural forest fragments in Northeast Brazil using elliptic Fourier analysis of leaf outlines. Kew Bulletin 63: 193-211.

2010. Elliptic Fourier Analysis of leaf outline shape in forest fragment populations of Anthurium sinuatum and A. pentaphyllum (Araceae) from Northeast Brazil. Kew Bulletin 65: 1-18.

Andrade, I.M., Mayo, S.J., Van den Berg, C., Fay, M.F.; Chester, M.; Lexer, C. \& Kirkup, D. 2007. A preliminary study of genetic variation in populations of Monstera adansonii var. klotzschiana (Araceae) from North-East Brazil, estimated with AFLP molecular markers. Annals of Botany 100: 1143-1154

2009. Genetic variation in natural populations of Anthurium sinuatum and A. pentaphyllum var. pentaphyllum (Araceae) from north-east Brazil using AFLP molecular markers. Botanical Journal of the Linnean Society 159: 88-105.

Andrade, I.M., Mayo, S.J.; Silva, M.F.S., Sousa, D.J., Matias, L.Q. \& Ribeiro, T.A. 2013. The Araceae in Ceará, Brazil: humid forest plants in a semi-arid region. Rodriguésia 64(3): 445-477.

Bogner, J. 1980. The genus Scaphispatha Brongn. ex Schott. Aroideana 3: 4-12.

Bogner, J. \& Gonçalves, E.G. 2002. Two new aroids from South America. Willdenowia 32: 323-329.

Boyce, P.C. \& Croat, T.B. 2014. The Überlist of Araceae, Totals for Published and Estimated Number of Species in Aroid Genera. Available at: www.aroid.org/genera/140601uberlist.pdf. Accessed on 02.03.2015.

Braga, R. 1960. Plantas do Nordeste, especialmente do Ceará. Imprensa Oficial, Fortaleza, p. 435-6.

Bunting, G.S. 1960. A revision of Spathiphyllum (Araceae). Memoirs of the New York Botanical Garden 10(3): 1-53.

Campos, C.G., Oliveira, J.R.A., Miguel, J.R. \& Jascone, C.E.S. 2008. Araceae da Estação Ecológica Estadual do Paraíso - Rio de Janeiro. Saúde \& Ambiente em Revista 1: 96-113.

Coelho, M.A.N., Soares, M.L., Calazans, L.S.B., Gonçalves, E.G., Andrade, I.M. de, Pontes, T.A., Sakuragui, C.M., Temponi, L.G., 
Buturi, C. \& Mayo, S. 2015. Araceae in Lista de Espécies da Flora do Brasil. Jardim Botânico do Rio de Janeiro. Available at: floradobrasil. jbrj.gov.br/jabot/floradobrasil/FB51. Acessed on 03 March, 2015.

Coelho, M.A.N., Waechter, J.L. \& Mayo, S.J. 2009. Revisão taxonômica das Espécies de Anthurium (Araceae) Seção Urospadix Subseção Flavescentiviridia. Rodriguésia 60(4): 799-864.

Croat, T.B. 1981. A revision of Syngonium (Araceae). Annals of the Missouri Botanical Garden 68: 565-651.

. 1990. The ecology and life forms of Araceae. Aroideana 11: 4-56. . 1991. A revision of Anthurium section Pachyneurium (Araceae). Annals of the Missouri Botanical Garden 76(3): 539-855.

1997. A revision of Philodendron Subgenus Philodendron (Araceae) for México and Central America. Annals of the Missouri Botanical Garden 84(3): 311-704.

Cusimano, N., Bogner, J., Mayo, S.J., Boyce, P.C., Wong, S.Y., Hesse, M., Hetterscheid, W.L.A., Keating, R. \& French, J.C. 2011. Relationships within the Araceae: comparison of morphological patterns with molecular phylogenies. American Journal of Botany 98(4): 654-668.

Fernandes, A. \& Bezerra, P. 1990. Estudo Fitogeográfico do Brasil. Stylus Comunicações, Fortaleza. 205p.

Fidalgo, O. \& Bononi, V.L.R. 1989. Técnicas de coleta, preservação de material botânico. Instituto de Botânica, São Paulo. 62p.

França, G.M.O, Filho, J.F.M, Pereira, C.M.O, Faria, G.A, Melo, F.V.S.T, \& Santos, J.G. 2009. Valor nutricional de Lemna valdiviana Phil. (Araceae) submetida a diferentes concentrações de fertilização com excremento de aves, Bahia. Biotemas 22(3): 19-26.

Gonçalves, E.G. 2000. Xanthosoma riparium (Araceae), a New Species from Goiás, Brazil. Novon 10(1): 26-28.

.2002. Sistemática e evolução da tribo Spathicarpeae (Araceae), Brasil. São Paulo, Brasil, Tese. Instituto de Biociência da Universidade de São Paulo. São Paulo. 148p.

2005. A revision of genus Dracontioides Engl. (Araceae), including a new species from Bahia, Brasil. Aroideana 28: 21-31.

Grayum, M.H. 1996. Revision of Philodendon Subgenus Pteromischum (Araceae) for Pacific and Caribbean Tropical America. Systematic Botany 47: 1-233.

Haigh, A., Mayo, S.J. \& Coelho, M.A.N. 2011. Four new species of Anthurium (Araceae) from Bahia, Brazil. Kew Bulletin 66: 123-132.

Instituto Brasileiro do Meio Ambiente e dos Recursos Naturais Renováveis - IBAMA. 1998. Plano de gestão e Diagnóstico Geo-Ambiental e Socioeconômico da APA do Delta do Parnaíba. Ministério do Meio Ambiente, Instituto de Pesquisas Sociais da Universidade Estadual do Ceará. Fortaleza. 8p.

Instituto Brasileiro de Geografia e Estatística - IBGE. IBGE Cidades. 2010. Available at: www.ibge.gov.br. Acessed on 06 February, 2015.

Landolt, E. 1986. Biosystematic investigations in the family of duckweeds (Lemnaceae) (vol. 2). Veroff. Geobot. Inst., Rubel, 1(71): 566p.

Madison, M. 1977. A revision of Monstera (Araceae). Contributions from the Gray Herbarium of Harvard University 207: 1-101.

Mayo, S.J. 1978. A new species of Anthurium (Araceae) from Bahia, Brazil. Bradea 2(42): 281-286.

. 1980. A new species of Philodendron from Trinidad. Aroideana 4(1): 20-22.

. 1984. Aspectos da fitogeografia das Araceae bahianas. (Aspects of the phytogeography of Bahian Araceae.). In Anais do 34 Congresso Nacional de Botânica 2: 215-227).
1986. Review of Chandra's Edible Aroids (1984). Tropical Agriculture Trinidad 63(2): 165-166.

. 1989. Observations of gynoecial structure in Philodendron (Araceae). Botanical Journal of the Linnean Society 100: 139-172. 1990. Problems of speciation, biogeography and systematics in some Araceae of the Brazilian Atlantic Forest. In Anais do II Simpósio de Ecossistemas da Costa Sul e Sudeste Brasileira. São Paulo, p. 235-258.

Mayo, S. J., \& Barroso, G. M. 1979. new pedate-leaved species of Philodendron from Bahia, Brazil. Aroideana 2: 82-94

Mayo, S.J. \& Andrade, I.M. 2013. A morphometric and taxonomic study of Monstera (Araceae) in Bahia, Brazil. Feddes Repertorium 124: 1-24.

Mayo, S.J., Bogner, J. \& Boyce, P. 1995. The Arales. In Monocotyledons - Systematics and Evolution (P.J. Rudall, P.J. Cribb, D.F. Cutler \& C.J. Humphries, eds.). Royal Botanic Gardens, Kew, p. 277-286.

. 1997. The genera of Araceae. Royal Botanic Gardens, Kew. 370p.

Mayo, S.J., Coelho, M.A.N., Ramalho, F.C., Andrade, I.M. \& Nicolson, D.H. 1998. Araceae. In Plantas Vasculares das Florestas Serranas de Pernambuco: Um Checklist da Flora Ameaçada dos Brejos de Altitude, Pernambuco, Brasil (M.F. Sales, S.J. Mayo \& M.J.N. Rodal, eds.). Universidade Federal Rural de Pernambuco, Imprensa Universitária, Recife, p. 110-112.

Nauheimer, L., Metzler, D. \& Renner, S.S. 2012. Global history of the ancient monocot family Araceae inferred with models accounting for past continental positions and previous ranges based on fossils. New Phytologist 195: 938-950.

Peel, M.C., Finlayson, B.L. \& McMahon, T.A. 2007. Undated world map of the Köppen Geiser climate classification. Hydrology and Earth System Sciences 11: 1633-1644.

Pontes, T.A. \& Alves, M. 2011. Padrões de distribuição geográfica das espécies de Araceae ocorrentes em fragmentos de floresta atlântica em Pernambuco, Brasil. Revista Brasileira de Biociências 9: 444-454.

Pontes, T.A., Van Den Berg, C., Andrade, I.M. de \& Mayo, S.J. 2014. Measuring relative flower size in Anthurium (Araceae) as a continuous quantitative character. Phytotaxa 178: 171-180.

Pott,V.J. \& Cervi, A.C. 1999. A família Lemnaceae Gray no Pantanal (Mato Grosso e Mato Grosso do Sul), Brasil. Revista brasileira de Botânica 22(2): 153-174.

Ramalho, F.C. 1994. Taxonomia e número cromossômico de representantes da família Araceae em Pernambuco. Dissertação. Universidade Federal de Pernambuco, Recife.174p.

Sakuragui, C.M., Mayo, S. \& Zappi, D. 2006. Taxonomic revision of Philodendron section Macrobelium. Kew Bulletin 60(4): 465-513.

Silva, M.F.S., Andrade, I.M. de \& Mayo, S.J. 2012. Geometric morphometrics of leaf blade shape in Montrichardia linifera (Araceae) populations from the Rio Parnaíba Delta, north-east Brazil. Botanical Journal of the Linnean Society 170: 554-572.

Temponi, L.G., Garcia, L.C.P., Sakuragui, C.M. \& Carvalho, Okano, R.M. 2005. Diversidade morfológica e formas de vida das Araceae no Parque Estadual do Rio Doce, Minas Gerais. Rodriguésia 56(88): $1-13$.

WCSP. 2015. World Checklist of Selected Plant Families. Facilitated by the Royal Botanic Gardens, Kew. Available at: http://apps.kew.org/ wcsp/Acessed on 29 Jun, 2015. 